\title{
Between Emulation and Assemblage: Analysing WFD Policy Transfer Outcomes in Turkey
}

\author{
Burcin Demirbilek * and David Benson \\ Environment and Sustainability Institute, University of Exeter, Penryn Campus, Penryn TR10 9FE, Cornwall, \\ UK; d.i.benson@exeter.ac.uk \\ * Correspondence: bd297@exeter.ac.uk; Tel.: +44-132-62-59415
}

Received: 11 November 2018; Accepted: 7 February 2019; Published: 14 February 2019

\begin{abstract}
Turkey's protracted European Union (EU) accession process has resulted in the transfer of environmental policy, primarily the water acquis. Despite a recent reversal in accession negotiations, this process is continuing and has thereby resulted in the active Europeanisation of Turkish water policy. However, the resultant pattern of Europeanisation remains poorly understood with questions arising as to whether policy transfer is leading to significant convergence with EU policy, or if a uniquely Turkish hybrid system of water governance is emerging. The paper therefore provides an analysis of transfer outcomes from the EU Water Framework Directive (WFD), using eight core institutional features: identification of river basins; transboundary cooperation; environmental objectives setting; characterisation of river basins; monitoring; cost recovery and water pricing; river basin management planning; and public participation. While analysis of legal frameworks and their implementation shows many areas of emulation, some features of the WFD in Turkey are an amalgam of pre-existing water institutions, the mimetic influence of integrated water resources management (IWRM) norms, EU policy and changing national water policy priorities: what we call assembled emulation. This observation has implications for future studies on policy transfer, Europeanisation, IWRM and Turkish accession.
\end{abstract}

Keywords: European Union; Turkey; Europeanisation; institutions; policy transfer; Water Framework Directive

\section{Introduction}

Integrated water resources management (IWRM) is a global paradigm for hierarchical water governance, with multiple variants visible according to national context [1]. Practical conceptualisations vary widely but IWRM essentially encompasses the integrated management of water and related resources at the river basin scale, in conjunction with multiple stakeholders, to ensure their equitable and sustainable use [1]. In the European Union (EU), IWRM is primarily implemented through the Water Framework Directive (or WFD). Introduced in 2000, the WFD has fundamentally transformed water governance across Europe through compelling the transfer of EU institutions for, inter alia, river basin management and planning, public participation and economic valuation of water resources into national policy structures, thereby contributing to a wider Europeanisation of environmental policy. Here, drawing upon rational choice institutional theory, 'institutions are conceptualized as collections of rules and incentives that establish the parameters on the behavior of individuals' [2]. 'Europeanisation' refers to the interaction between the EU and its Member States as well as externally with non-EU states, with this typically measured through formal, rule-based institutional change and its effects in domestic political contexts resulting from European level influence [3]. In particular, rational institutionalism explanations of Europeanisation interpret such domestic adaptation as stemming from the transfer of EU rules [3]. As a result of this process in 
the water policy sector, different national implementation approaches for the WFD exist across the EU, prompting development of a significant academic literature examining its effects [4-6].

Europeanisation of water governance under the WFD is not restricted to EU countries. The EU has actively transferred WFD institutions to non-EU states, either through a process of policy transfer via network influence [7], or more coercive forms of transfer [8] whereby these states are incentivised to adopt them through accession conditionality. One such country is Turkey, which initially transferred WFD institutions in response to its $1999 \mathrm{EU}$ accession agreement [9]. A critical requirement of the Copenhagen Criteria for accession to the EU is the obligation on candidate countries to adopt the environmental acquis; the body of EU laws and policy norms concerning the environment. Despite a declining accession process in recent years, as is due to a changed domestic policy context, Turkey has conversely continued to implement the WFD as part of the water acquis, leading to significant institutional change to its pre-existing policy structures, although a detailed analysis of the effects of this transfer is lacking. A critical question to emerge from this transfer process therefore concerns the extent to which external Europeanisation has led to convergence around WFD institutions in Turkish water policy.

As discussed further below, answering this question involves consideration of three dimensions of policy transfer. Firstly, determining the 'object' $[10,11]$ of transfer, in this case the element of WFD policy, is of central importance for measuring convergence. Here, we focus on WFD institutions, or formal rules [2], as a measure of policy change. Secondly, the degree of transfer in institutional outcomes is a critical factor. Convergence is compatible with the complete adoption of EU water institutions in national policy frameworks. Thirdly, while transfer of WFD institutions to Turkey provides a key measure of convergence [9], consideration of their influence on the governance of water is also required. For this reason, this paper examines institutional transfer across the policy process in Turkey.

Our analysis is structured in the following way. We initially set out our methods, which involve developing an analytical framework for measuring the effects of external Europeanisation in the transfer of WFD institutions to Turkey, based upon its key implementing requirements. A brief context to the transfer of the WFD to Turkey is presented before this framework is applied to examine the integration of these institutions into Turkish water policy, in order to assess the degree of convergence. Finally, the analysis is used to discuss the future development of IWRM in Turkey along with the implications of the study for wider IWRM research.

\section{Developing an Analytical Framework for Policy Transfer under Europeanisation}

Policy transfer is understood to be an important mechanism within Europeanisation for ensuring convergence with EU institutions [12,13]. This process has been studied with regards to convergence within EU states [14], but also to non-EU states via political enlargement, including in respect of Turkey $[15,16]$. A rich literature has also evolved to provide analysis of how the WFD has been implemented in EU states [6]. However, the transfer of EU environmental institutions, particularly for water management, to non-EU states has only received limited theoretical attention in the academic literature [17]. For example, Fritsch et al. [7] examine the role of the EU Water Initiative (EU-WI) in facilitating transfer of the WFD to African and Central Asian states, but they do not explicitly use a policy transfer framework. Studies on EU water policy in Turkey are similarly descriptive [18-20], suggesting the need for more theoretically-informed research. Utilising a policy transfer approach for assessing WFD convergence requires consideration of several factors: the actual focus or 'object' [10] of transfer; policy outcomes and the degree of convergence; and qualitative indicators of transfer. This section therefore examines these factors to develop an analytical framework that is then applied to qualitative data on Turkish water policy, as is drawn from semi-structured interviews and documentary analysis. 


\subsection{Object of Analysis}

The policy transfer literature identifies several objects for analysis. In his studies of lesson-drawing, Rose [21,22] primarily refers to programmes as objects for public policy learning. However, this conceptual emphasis is rather limiting. Dolowitz and Marsh [10], in their classic review of this literature, therefore identify six objects of policy transfer: 'policy goals, structure and content; policy instruments or administrative techniques; institutions; ideology; ideas, attitudes and concepts; and negative lessons.' They later return to this typology to add 'policy programs' to the list [8]. While by no means exhaustive, these features provide an analytical focus for policy transfer research [11]. For the WFD, we propose an emphasis on rule-based institutions [2] as the EU primarily focuses on transferring this element to states through the Europeanisation of environmental policy [23]. Here, directives, the most common EU environmental policy instrument, specify the general institutional requirements of policy to be achieved but provide some implementation flexibility through their legal transposition in national contexts [24].

\subsection{Measuring Outcomes}

Having established the object of transfer to be measured, the notion of policy outcomes must be considered. In other words, the actual results of policy transfer as a reflection of convergence. Again, the academic literature provides significant discussion of this subject, allowing the construction of an analytical framework. Outcomes can be placed along a continuum depending on the degree of transfer. Rose [21] argues that lesson-drawing by policy-makers can result in five outcomes: copying; emulation; hybridisation; synthesis; and inspiration. Copying equates to direct transfer of policy 'using practice elsewhere literally as a blueprint' [21]. Emulation, meanwhile, refers to 'adoption, with adjustment for different circumstances, of a programme already in effect in another jurisdiction' [21]. Hybridisation and synthesis encompass the combination of different programmes from other countries, while inspiration refers to external programmes merely providing an 'intellectual stimulus' for domestic action [21]. Reflecting back on this earlier study, Dolowitz and Marsh [10] support this categorisation, although state that ' $[w]$ e prefer to combine the two related categories of hybridization and synthesis'. By 2000, they still used this approach but only referred to the emulation category to denote combinations of policy transfer [8]. More latterly, Bulmer et al. [14] understand emulation as 'entailing the 'borrowing' of a policy model more or less intact from another jurisdiction' thereby allowing for 'adaptation to accommodate contextual differences', but otherwise they use Rose's original concepts.

The literature on policy transfer has since adopted other concepts to measure the degree of transfer occurring [11]. Recent research has focused on the notion of 'policy assemblage' [25-28]. Definitions are diverse, but for Prince [25] an 'implemented policy is an assemblage of texts, actors, agencies, institutions, and networks [ ... ] at particular policy-making locales that are constituted by a complex of relations, including the increasingly spatially stretched relations constitutive of globalisation'. Although often associated with critical theoretical studies of policy translation and mutation [28], assemblage also recognises that policies which 'travel' can be drawn from multiple sources, both domestic and external, and therefore includes elements of influence as well, often reflecting global neoliberal agendas. While methodological questions arise over empirically researching the translational nature of policy assemblages [29], the concept can provide a useful heuristic device-in a positivist sense-for examining transfer outcomes that complements earlier, more rational conceptualisations.

For WFD transfer, copying would equate to the direct transfer of EU institutions by Turkey, i.e., the policy would be the same, resulting in complete convergence. If emulation is evident, WFD institutions would be transferred essentially intact but modified to fit existing practice during this process, equating to high levels of convergence. Partial convergence would be apparent where transfer of institutions has resulted in an amalgam of policy, combining elements of pre-existing domestic practice with the WFD and other external sources, i.e., assemblage. Convergence would be limited where the WFD has provided only superficial institutional influence for Turkish water policy. 
For analytical purposes, a distinction should also be made between adopted policy and its implementation. The policy process can be divided into sequential stages that equate to the decisional and post-decisional phases of policy-making [30]. In WFD transfer it is therefore important to not only examine how institutions have been formally interpreted in Turkish policy, but also their implementation on the ground. Given the multi-level nature of the WFD, analysis should also focus on river basin management planning: the core procedural outcome of the Directive.

\subsection{Indicators of Policy Transfer}

In assessing the degree of policy transfer occurring in such outcomes, it is necessary to outline the key institutions of the WFD in order to provide qualitative indicators for assessing implementation in Turkey. Under the legal framework of the WFD, Member States are required to implement several rule-based institutions or 'articles' relating to specific implementing features (Table 1). For example, Article 3, 1. stipulates that they should initially 'identify [ ... ] individual river basins' in order to create so-called 'river basin districts' (RBDs) as a fundamental unit of implementation [31]. Since the adoption of the WFD, 124 river basin districts have been established, although they vary in basin size, population, land use and water pollution issues. For example, the Danube River Basin covers over $800,000 \mathrm{~km}^{2}$ and 19 countries [32], while Cyprus only has one RBD which extends across a total area of $9250 \mathrm{~km}^{2}$ [33]. River basin districts can also encompass non-EU states (Article 3, 5.) and therefore requires that 'appropriate coordination' is undertaken 'with the relevant non-Member States' in order to achieve harmonisation in management throughout the basin [31]. Implementation has witnessed the development of transboundary coordinating institutions between EU and non-EU states, in addition to bodies for cross-border management. For example, implementation of the WFD in the Danube River Basin is coordinated by the International Commission for the Protection of the Danube River (ICPDR), to which 14 countries and the EU are contracting parties [32]. Environmental objectives must be set and a programme of measures adopted for each river basin district in order to prevent deterioration of water quality and achieve 'good surface water status' [31]. A characterisation analysis of the basin should be undertaken that reviews human impacts on water resources and provides 'an economic analysis of water use' (Article 5, 1.) [31]. Once established, the programme of measures for each district should be monitored against water quality objectives (Article 8). Member States are also obliged to impose cost recovery and water pricing to ensure that efficient use of water resources is made (Article 9). All of these measures should then be incorporated into a river basin management plan for each district, which is periodically reviewed (Article 13, 1.) [31]. Finally, development of the plan should be conducted in conjunction with public participation (Article 14, 1.). The 'active involvement of all interested parties' should be encouraged, particularly in producing, reviewing and updating the plan, while plan information should be made publicly available in this process to facilitate consultation [31]. Key institutional features and institutions of the WFD are summarised in Table 1 in order to provide a set of indicators for comparative analysis.

Table 1. Institutional features and institutions of the Water Framework Directive (WFD) [31].

\begin{tabular}{ll}
\hline \multicolumn{1}{c}{ Institutional Features } & \multicolumn{1}{c}{ Institutions } \\
\hline 1. Identification of river basins & $\begin{array}{l}\text { Article 3, 1.-'Member States shall identify the individual river basins lying within } \\
\text { their national territory and [ . . ] shall assign them to individual river basin districts' }\end{array}$ \\
\hline \multirow{2}{*}{ 2. Transboundary cooperation } & $\begin{array}{l}\text { Article 3, 5.-'Where a river basin extends beyond the Community, the Member State } \\
{[\ldots] \text { shall endeavour to establish appropriate coordination with the relevant }} \\
\text { non-Member State, with the aim of achieving the objectives of this Directive } \\
\text { throughout the river basin district' }\end{array}$ \\
\hline 3. Environmental objectives setting & $\begin{array}{l}\text { Article 4, 1.-'Member States shall implement the necessary measures to prevent } \\
\text { deterioration of the status of all bodies of surface water'. 'Member States shall protect, } \\
\text { enhance and restore all bodies of surface water [ ... ] with the aim of achieving good } \\
\text { surface water status' }\end{array}$ \\
\hline
\end{tabular}


Table 1. Cont.

\begin{tabular}{|c|c|}
\hline Institutional Features & Institutions \\
\hline 4. Characterisation & $\begin{array}{l}\text { Article 5,1.-Member States are required to undertake the following for each river } \\
\text { basin district: 'an analysis of its characteristics, a review of the impact of human } \\
\text { activity on the status of surface waters and groundwater, and an economic analysis of } \\
\text { water use'. Art. 7.-Member States must identify waters used for abstraction. }\end{array}$ \\
\hline 5. Monitoring & $\begin{array}{l}\text { Article } 8,1 .- \text { 'Member States shall ensure the establishment of programmes for the } \\
\text { monitoring of water status' }\end{array}$ \\
\hline 6. Cost recovery and water pricing & $\begin{array}{l}\text { Article } 9,1 .- \text { 'Member States shall take account of the principle of the recovery of costs } \\
\text { of water services, having regard to the economic analysis ... and in accordance }[\ldots] \\
\text { with the polluter pays principle' and 'that water-pricing policies provide adequate } \\
\text { incentives for water users to use water resources efficiently' }\end{array}$ \\
\hline $\begin{array}{l}\text { 7. River basin management } \\
\text { planning }\end{array}$ & $\begin{array}{l}\text { Article } 13,1 .-{ }^{\prime} \text { Member States shall ensure that a river basin management plan is } \\
\text { produced for each river basin district' }\end{array}$ \\
\hline 8. Public participation & $\begin{array}{l}\text { Article } 14,1 .- \text { 'Member States shall ensure that, for each river basin district, they } \\
\text { publish and make available to the public, including users,' relevant plan information. }\end{array}$ \\
\hline
\end{tabular}

\section{Methods}

These 8 institutional indicators were then used to analyse the degree of WFD transfer that has occurred in Turkey. Qualitative data comprising primary, secondary and tertiary documentary sources were combined with policy-maker interviews to assess the extent to which these key institutional features of the WFD are integrated into Turkish water governance. Legal analysis was conducted on national water policy, primarily the current draft Water Law (discussed further below) and associated national by-laws for implementing the EU water acquis. Further documentary analysis was undertaken of national and river basin district WFD implementation reports, official implementation data and published academic studies. Interview data was derived from questioning Turkish national officials, EU representatives and policy actors in two case river basin studies: the Konya and Büyük Menderes. Both river basins are significant since they have served as pilots for the WFD implementation process (see below).

In total, 48 interviews were conducted between 2017 and 2018. This total included 3 interviews with European Commission officials (DG NEAR (Directorate-General for Neighbourhood and Enlargement Negotiations) and DG Environment) in Brussels. The main body of interviewing was undertaken with Turkish government officials in Ankara, with 19 participants from the Ministry of Forest and Water Affairs (MoFWA), 2 from the Delegation of the European Union to Turkey and 7 from the Ministry of Environment and Urbanisation (MoEU). Interviews completed in river basins included 11 in the Konya (Closed) Basin and 6 in the Büyük Menderes Basin. Interviewing followed a semi-structured approach of asking standardised questions around how transfer of the WFD was occurring and the extent to which it has been achieved in Turkey. Interviews typically lasted one hour and were recorded for later transcription and analysis.

The analysis of documentary sources and interview transcripts centred on whether WFD institutions have been directly transferred ('copied') into Turkish policy at national and river basin levels. From this analysis an assessment could then be made as to whether policy transfer has led to convergence. Conversely, the analysis also considered whether these institutions have been modified in the policy process or are absent, in which case policy transfer can be considered less effective and hence subject to emulation, assemblage or inspiration.

\section{Results}

To what extent has the WFD transferred to Turkey under the Europeanisation process? In considering this question, this section first goes back in time to consider the context to Turkish water policy in order to track the adoption of the Directive: a process which is still ongoing. Unlike the adoption process in EU Member States, transfer has not followed from initial transposition of the Directive into Turkish national legislation and policy, leading to implementation at the river basin 
level. Rather, a twin-track approach has evolved via incremental national level institutional change alongside river basin level transfer of WFD institutions through various EU-supported initiatives known as 'projects'. Therefore, national (legal) and river basin (planning implementation) processes are considered together.

\subsection{A Short History of Turkish Water Policy: From Localism to Europeanisation}

Prior to 2002, Turkish water policy had accumulated into a body of uncoordinated water-related legislation with no single overarching water law. This situation occurred through the incremental development of a dense set of national and local legislation and national level implementing bodies in response to several discursive waves or 'paradigms' of policy development [9]. Such institutional 'layering' [34] began soon after the creation of the Turkish Republic with the adoption of national water legislation $[35,36]$. Prior to this point, reflecting the governance system established by the Ottoman Empire, water was essentially a local responsibility [37]. Centralisation of Turkish water policy continued in 1934 with the establishment of the national Ministry of Public Works, whose primary function was to support municipal drinking water provision. An era of centralised integrated water planning then proceeded under a national five-year development plan adopted in the same year [38]. Further centralisation occurred in the post-war period, primarily through the creation of the General Directorate of State Hydraulic Works (DSI in the Turkish acronym) in 1954. Water infrastructure for hydropower, flood control and irrigation became national economic planning priorities, alongside significant development of drinking water supply systems. Large integrated water management projects, influenced by practice in countries such as the USA and funded by international donors, became prevalent. By the 1980s, neoliberalism had exerted greater influence on the direction of policy. In 1981, municipal water and sanitation bodies were established to operate with independent budgets and the capacity to receive loans from foreign sources such as the World Bank, underwritten by government guarantees [39]. Privatisation has informed the direction of Turkish water policy in the intervening period, with the growing influence of foreign development loans becoming apparent.

Turkish water policy has more recently been informed by the Europeanisation agenda [9]. A central component of Turkey's EU water policy transfer strategy has involved adopting WFD institutions. This process started in 2002 through the EU-sponsored MATRA 'Implementation of the WFD in Turkey' (2002-2004) (MATO1/TR/9/3) project [40]. As a result, 25 river basin districts were identified nationally, with technical and financial assistance for implementation provided by the EU [9]. Turkey has since adopted several national by-laws and other legal measures to support this process, for example, the By-Law on the Determination of Sensitive Water Bodies in 2016. Several other by-laws are currently under development regarding, for instance, drinking water basin protection and water loss leakage control [9]. However, the most significant policy innovation for WFD implementation, a new national Water Law (WL), is still awaiting adoption $[9,41]$. Although discussed further below, the Water Law is designed to integrate Turkish policy with the WFD by endorsing the principles of river basin management and planning [41,42]. In parallel to national legal policy changes, Turkey has pursued implementation 'on the ground' through a series of additional EU-funded projects. The 'Strengthening the Capacity of Sustainable Groundwater Management in Turkey' (2006-2008) project was funded by the Dutch government to support implementation of the EU Groundwater Directive and WFD in river basins under the MATRA programme. It was followed by the EU Twinning Project 'Capacity Building Support to the Water Sector in Turkey' (2007-2009) which was intended to facilitate transposition of the WFD, using the Büyük Menderes river basin district as a pilot to develop a river basin plan [9]. Further Twinning Projects were then undertaken for assessing surface water bodies and water quality monitoring in line with the WFD (2010-2014), plus the parallel Floods Directive (2010-2014). Finally, the period since has involved preparation of River Basin Action Plans (RBAPs) and River Basin Management Plans (RBMPs).

This process was initiated in 2010 when RBAPs were prepared for 11 basins (Marmara, Susurluk, Kuzey Ege, Kücük Menderes, Büyük Menderes, Burdur, Konya Kapalı, Ceyhan, Seyhan, Kızılırmak, 
Yeşilırmak) [9]. Plans for the remaining 14 basins were subsequently produced between 2011 and 2013. The RBAPs consist of several elements: a general description of the river basin district; field surveys and determinations of the environmental context; water quality classification; a calculation of pollutant loads; identification of prominent environmental problems in the basin and potential solutions; the planning of urban wastewater treatment plants; an overview of the preparation of the RBAP; and GIS data. By 2023, it is anticipated that the process of converting RBAPs to RBMPs will be completed. To support this aim, the Draft Büyük Menderes River Basin Management Plan was prepared under the MATRA programme. Currently, RBMPs are being developed for four other basins: the Meriç-Ergene, Konya and Susurluk RBDs under the Conversion of River Basin Action Plans into River Basin Management Plans (2015-2018) (TR2011/0327.21.05) project in collaboration with the Spanish Ministry of Forestry and Water Affairs [42]. To support conversion, stakeholder meetings have been staged to inform the public of plan development and invite responses.

\subsection{Similarities with the WFD Model}

As a result of this twin-track Europeanisation approach, implementation of the WFD in Turkey bears many similarities with the EU model. Although policy changes have been introduced to transfer the broader EU water acquis [9], national institutional innovations are best understood through examination of the draft Water Law [41], still under consideration by Turkish government ministries, adopted by-laws and implementation in river basins. These de jure institutional changes can therefore be considered sequentially alongside de facto implementation at the river basin scale.

Kibaroglu and Sumer, in their preliminary analysis [43], show that the draft WL broadly integrates with key WFD institutional requirements. The Turkish Draft Law will, once it is completed and adopted, recognise the concept of the river basin district, i.e., Article 3, 1. WFD (see Table 1). Water resources will therefore be legally organised around regional scale basin management [41]. Article 1, 1. (see also Article 4, 1.) of the draft WL thereby refers to the purpose of the Law as ensuring sustainable use of water resources using planning based on the watershed [41]. Although 'watershed' is most commonly employed in the USA to mean both catchment or river basin scales [44], the WL then states that waters should be assessed 'primarily in the basin' (Article 4, 1(a)) [41]. Watershed and basin are terms used seemingly interchangeably throughout the text, but application suggests that the WFD term is favoured for implementation. This obligation is already implemented through a national by-law, adopted in 2012 and revised in 2017 (By-Law on the Protection of Water Basins and Preparation of Management Plans 2012) [9]. The identification and assignment of river basin districts, as required under Art. 3 WFD, has also occurred under the MATRA project (see above) with the establishment of the 25 RBDs: the national Water Law will therefore effectively provide legal endorsement for their creation once fully adopted. The recent shift towards adopting RBMPs for all river basin districts also supports implementation of Article 13 WFD (see Table 1). The draft WL specifies a requirement, under Article 7 (1), that a 'management plan' is prepared by the Ministry of Forestry and Water Affairs (now the Ministry of Agriculture and Forestry) for Cabinet approval [41]. This plan should be compatible with the National Water Plan (Article 6 of the WL) and consider stakeholder participation, the impacts of climate change, water management at basin level and water allocation [41]. Water transfer can occur by considering basin needs and usage priorities where adequate water is available to transfer. For the Konya basin, this is an essential obligation due to the serious drought conditions currently being experienced.

Additionally, the WL prioritises the WFD notion of achieving environmental objectives for 'good' water quality (implementing Art. 4 WFD—see Table 1) through river basin management [41]. Article 4 of the WL covers the reuse of waste waters, good water status for surface and groundwaters, participatory approaches and eliminating the factors which negatively affect water quality and quantity [41,45]. Kibaroglu and Sumer [43] show how the draft WL 'establishes a hierarchy of uses [... ] which seems to confirm the centrality of environmental objectives'. Article 5, 1. WL states that in establishing the right to use water resources, 'water needs for natural life' is prioritised above, 
inter alia, drinking water, agricultural irrigation, energy, industrial uses, trade tourism, recreation and transport [41,45]. A national by-law for protecting water resources now supports this hierarchy [9]. Draft RBMPs also set out environmental objectives for water resources at the river basin scale [46]. For example, the Draft Version of the Konya Basin Management Plan closely follows Art. 4 WFD by adopting 'good status' objectives for surface and ground waters plus protected areas [47], a feature replicated in other RBMPs [48].

Both national legal measures and practical implementation shows that the WFD requirement for monitoring water resources has also been transferred to the Turkish system. The draft WL states that water monitoring should be conducted by government ministries [41], reflecting the requirements of Art. 8 WFD (see Table 1). Article 8 WL determines that water monitoring is conducted by the Ministry of Forestry of Water Affairs. However, if necessary, it can delegate this duty to the DSI and municipalities [41,45]. Few specific details of monitoring procedures are specified in the draft WL, but they are outlined in a supporting national by-law (By-Law on the Monitoring of Surface Waters and Groundwaters 2014) for WFD implementation [9]. In practice, monitoring systems are now being established in river basins [47]. In depth monitoring of water bodies has been undertaken for the production of the RBAPs and RBMPs [46-48]. The Draft Büyük Menderes RBMP shows that a network of 79 monitoring stations for 75 water bodies is now established to test biological, hydromorphological and physical-chemical elements of waters [48]. Interviews also showed that national and local policy actors were successfully learning monitoring approaches from EU technical experts.

Full cost recovery, central to the WFD (Art. 9-see Table 1), is also a key WL principle. Article 4, 1(e,f) WL thereby refers to '[p]ricing for water management services' and requires that '[p]ollution prevention costs are paid by the polluters; water supply costs are paid for water users' [41]. Article $23(1,2)$ WL moreover specifies how water management services should be charged by the relevant ministry and managed by the DSI $[41,45]$. To an extent, this requirement should support implementation of WFD Article 9 which emphasises full cost recovery for water services to increase use efficiency. Indeed, Article 23 of the draft WL thereby refers to 'the principle of full cost' as a means of financing water provision $[41,45]$. Evidence from the interviews and draft RBMPs shows that cost recovery is now being considered in the development of programmes for implementing measures [46].

Public participation has, in addition, formed an important component of RBMP development, with stakeholder engagement mechanisms established at the river basin scale. Although the draft WL does not include public participation under its core Article 4 principles, when specifying watershed plan development Article 7 (1) does nonetheless require that this should occur through 'a participatory approach' [41]. As public participation is fundamental to the WFD (see Table 1), this aspect could be seen as positive when considering the effective transfer of EU institutions. Data from the river basin planning process interviews and documentary analysis would underline this requirement, with stakeholder meetings held during RMBP development [46]. For example, planning information and consultations were provided for the public in the Büyük Menderes process, the latter taking place through stakeholder meetings [48].

\subsection{Differences with the WFD Model}

However, there are some significant differences between Turkey's transfer of the WFD and the EU model. Again, we can start by analysing de jure institutional change. Divergence is most apparent when considering Article 3, 5. of the WFD (see Table 1). This Article compels Member States to engage in transboundary cooperation for interstate waters, but Turkey has not fully implemented this institutional requirement. Five main transboundary basins are found in Turkey: the Maritza (Meric); Euphrates-Tigris; Aras; Coruh; and Asi. According to the DSI, Turkey has historically sought to promote cooperation through bilateral agreements with its riparian neighbours [49]. Limited cooperation has subsequently occurred in the Maritza basin between Turkey, Greece and Bulgaria, with bilateral agreements signed with Greece for flood protection, erosion control, water diversion and environmental protection [50]. For example, Greece and Turkey signed a Memorandum of 
Understanding Concerning Cooperation on Environmental Protection in 2001 [50]. But multi-lateral, interstate river basin institutions of the type established in the EU for WFD implementation are not evident, particularly with Middle East states and Georgia. After construction of the Atatürk, Keban and Karakaya dams on the Euphrates in the 1960s, Turkey became embroiled in disputes over water use with downstream Syria and Iraq. A Joint Technical Committee was created by Turkey and Iraq in 1981, followed by the signing of a Protocol between Turkey and Syria regarding the supply of water in 1987 [51]. Following further disagreements, a Joint Declaration of the High-Level Strategic Cooperation Council was signed between Turkey and Iraq in 2008 that resulted in a Memorandum of Understanding on water use in 2009. Despite some cooperation then occurring, ongoing conflicts in Syria and Iraq have significantly reduced transboundary coordination [52].

The setting of environmental objectives is broadly encompassed by the draft $\mathrm{WL}$, and ecologically 'good' water status is considered in RBMP development. However, Turkey arguably has a different emphasis in objectives setting than that anticipated by the WFD, where the latter has explicitly targeted improving water quality and preventing its deterioration alongside other water uses. Despite the hierarchy of uses in the WL (Article 5) [41], drinking water provision is still considered as pre-eminent by the Government in its strategic development priorities, above water for 'natural life'. Moreover, water allocation for non-environmental (i.e., economic) uses underpins the language of national policy in the WL, forming a significant part of its legal requirements [41]. In practice, in the RBDs, agricultural, industrial and energy water provision is still prioritised over water for environmental services, reflecting the past development of water resources through large-scale engineering projects.

As identified above, characterisation of Turkey's river basins has been undertaken in line with Article 5 WFD, but full cost recovery remains a problem area [46]. The draft WL does explicitly identify this principle as a means of financing water provision but, as Kibaroglu and Sumer [43] point out, 'setting up a robust implementation scheme is another issue'. For this reason, the Ribamap project [46] in its review of Turkish WFD implementation stresses the need to establish 'an economic financial regime for the use of water in a new Water Act' that brings together measures currently dispersed across the legal system in Turkey. Economic analyses of river basins conducted, it argues, should provide sufficient information to allow assessment of the levels of cost recovery but also estimations of potential costs of measures for achieving environmental objectives, both of which appear lacking in the Turkish system [46].

In the same vein, Article 4 WFD (see Table 1) sets times for meeting objectives by 'achieving good ecological potential and good surface water chemical status at latest 15 years' after the adoption of the Directive [31]. However, the WL (Article 4) does not specify timelines, primarily because of potential difficulties faced in meeting objectives [41,53]. In addition, Article 7 of the draft WL [41], which provides details about preparation of the management plans, does not specify a schedule to renew them whereas Article 13 WFD mandates that RBMPs shall be reviewed and updated at the latest 15 years after the Directive's adoption, and every six years thereafter. The draft WL therefore has more general requirements for meeting objectives than the WFD.

Other differences exist in how public participation is interpreted. While the public was encouraged to comment on the draft Water Law preparation in 2012, they were subsequently excluded from its revisions after criticisms were submitted [43]. The Water Law itself does not set out public consultation procedures [41] but this aspect has nonetheless become an integral part of the RBMP development through implementation of the national by-law, with stakeholder meetings staged in the river basin districts [46]. That said, the WFD's prescriptive definition of what public participation should entail, under Article 14 (see Table 1), is not replicated in Turkey: interviews suggested that stakeholder meetings have lacked citizen engagement and often followed a more technocratic model of including institutional, academic and business actors to the exclusion of local people (see also [46-48]). In Büyük Menderes, for example, information was made available via websites and newspaper reports yet only three stakeholder meetings and local consultations were held, each featuring little public engagement [48]. As the Ribamap [46] concludes: 
'Public participation is a prerequisite for the approval of the Action Plans in the River Basin Management Plans that comply with the WFD. The law must answer to this challenge. Initial solutions of indirect participation have also been suggested (through organizations and institutions representing different interests and sectors) integrated in each of the suggested organizational models.'

\section{Discussion}

In theoretically analysing the degree of institutional transfer occurring, we can return to our continuum of transfer outcomes. Analysis would show that Rose's [21] notion of direct copying, and indeed complete convergence, can be discounted since there is no exact replication of WFD institutions in Turkish legal frameworks or implementation practices. However, this is not unexpected since, as a directive and not a regulation (regulations are directly applicable in Member State law and hence do not require transposition), the WFD only requires transposition thereby allowing, as across the EU, some degree of flexibility in application. For example, river basin district establishment in some EU states has been interpreted to mean developing planning that maps onto specific hydrological units, while in others RBDs are essentially regional scale reporting devices that encompass several river basins. Public participation has also been interpreted in multiple ways according to national context, leading to a patchwork of practices and degrees of effectiveness [5,6]. In fact, there are widespread differences in institutional implementation across European states [54,55], suggesting that complete convergence is not a feature of the WFD generally.

At the other end of the continuum, we can also discount the EU WFD as merely providing policy 'influence' $[8,10,21]$ for Turkey's IWRM programme. This transfer outcome would imply Europeanisation is merely incidental as an intervening variable to the WFD transfer process. Clearly this assumption is not credible for the situation in Turkey, given the degree of similarity with the EU approach in terms of river basin planning and other WFD features. Additionally, Turkey was compelled to adopt the water acquis in its entirety as a Copenhagen conditionality requirement: the former process continuing even though the latter has stalled. Turkey's continued production of WFD implementation reports and cooperation with the EU [46] would underline this point.

We could then understand transfer of WFD institutions under Europeanisation as more indicative of emulation rather than hybridisation, i.e., significant convergence. While hybridisation, according to Dolowitz and Marsh [10] refers to combining programmes from two or more external sources, which would not be appropriate in the case of Turkey, emulation implies transfer of key WFD institutions but with some minor allowance for contextual conditions. This feature is visible in the adoption of WFD institutional requirements in the WL and implementation of the Directive on the ground. If we take the example of establishing river basin districts and developing river basin planning, Turkey has taken significant steps to fulfilling both requirements. Characterisation of water resources has also been undertaken, along with the adoption of WFD principles of 'polluter pays', 'full cost recovery' and monitoring. Public participation, meanwhile, is also an accepted norm in the RBMP process in Turkey. Yet, rather than pure emulation, some elements of the WFD in Turkey are manifestly not derived directly from EU policy after marginal adjustment for context. Here, they could be described as an assemblage of EU institutions, pre-existing water norms and practices plus learning from other states around integrated water resources management, i.e., only partial convergence. A case in point is Article 3, 5. of the WFD, which has not been entirely adopted by Turkey. Although Turkey undertakes some minor bilateral cooperation with Greece and Bulgaria, for geo-political reasons-partly historical and partly pragmatic-it does not fully coordinate its actions with Georgia, Syria or other southern neighbours. The reasons are complex, reflecting long-standing disagreements with bordering states and the fractious political situation in the region [51,52]. Also, although Turkey does implement the WFD requirement for 'full cost recovery', it has a significantly different meaning in this context. In their view, Kibaroglu and Sumer [43] argue that the WL is primarily a vehicle for continuing the neoliberal privatisation process initiated in the 1990s. Finally, the WFD has been 
'layered' [34] over a pre-existing institutional structure of water governance that drew on integrated water resources management practices, primarily from the World Bank, which were adopted from the 1980s onwards (See Mukhtarov for an analysis of policy translation and IWRM in Turkey [56]). Pierson's concept of 'path dependence' [57] or the institutional inertia of past interventions is helpful in explaining the current situation. As a consequence of previous IWRM transfer supported by foreign donors, management of water resources in Turkey still reflects a top-down, engineering development 'paradigm' [1] which emphasises the quantitative aspects of water provision for agricultural, energy or industrial use rather than the environmental quality objectives explicitly prioritised by the WFD (Article 4). Indeed, evidence from the RBMPs shows that similar derogations to those allowable under the WFD could be used by Turkish policy-makers to offset any substantial investments in improving the 'good' ecological status of waters [47]. Significant arguments have already developed in the EU over the application of such derogations for cost recovery in WFD implementation, thereby illustrating the widespread problem of interpreting this institutional requirement due to domestic political contexts [58]. This feature additionally reflects the way in which de jure WFD institutions generally have been redefined by EU national governments to satisfy de facto political considerations in implementing the Directive [59].

\section{Conclusions}

Turkey's adoption of the WFD raises an interesting contradiction whereby implementation of key institutions continues despite declining EU accession imperatives [9]. At face value, when considering policy transfer outcomes under this Europeanisation process, it is possible to show that emulation is evident, i.e., partial convergence. Turkey has largely transferred WFD institutions into its national legal frameworks and implementing structures at the river basin scale, with the essential DNA of the EU model visible in the system now evolving. Critically, however, significant differences remain. Most notably, the WFD compels transboundary cooperation for water resources, but Turkey's application of this institutional requirement is limited due to an assemblage of historical and geo-political factors. In addition, features such as full cost recovery, environmental objectives attainment and public participation are interpreted differently. As a result, we could speak of an 'assembled' emulation which, as Turkey moves along the continuum of policy transfer, may one day equate to fuller correlation and hence convergence with the EU approach. An alternative hypothesis is that, if accession incentives decline further due to domestic political conditions, IWRM in Turkey may evolve to become a quasi-WFD model, which cherry-picks principal institutional elements of the EU approach but is tailored for the Turkish context. This type of approach may also provide a model for other non-EU states who aim to implement a system of IWRM governance but lack the political desire or technical capacity to follow the WFD in its entirety. It may also provide lessons for the EU itself in revising the WFD in response to implementation issues, particularly in the Mediterranean region, that highlight the need for institutional innovation [60] and better institutional ' fit' with contextual conditions $[61,62]$.

Such research also has implications for academic investigations into policy transfer, the WFD and IWRM more generally. Firstly, research is required into how WFD transfer is impacting water governance transformations in Turkish river basins, and particularly how individual actors are socially constructing its institutions through learning and socialisation [9]. Secondly, this research can help inform debates on EU policy transfer under conditions of declining accession incentives or even 'de-Europeanisation'. Further investigations into these dynamics will contribute to an emerging literature on this subject [63-65]. Thirdly, some reflection on how institutional implementation issues in Turkey compare to practice in existing EU states could be considered, particularly in areas such as public participation and cost recovery. Finally, the EU is now actively promoting WFD institutions globally through its regional Water Initiatives: multi-lateral policy transfer networks comprising EU bodies, governments and epistemic communities [7]. New forms of IWRM governance are consequently emerging but research is required into how $\mathrm{EU}$ transfer is affecting governance outcomes 
in non-EU states [7]. Of interest is whether WFD institutions are transferring directly, partially or merely providing influence due to contextual constraints in state receiving environments. In addition, consideration is required as to whether wholesale 'packaging' [66] of WFD institutions is occurring or if transfer involves individual policy components, i.e., a pick-and-mix approach. Viewing such processes through the related explanatory lenses of policy transfer, lesson-drawing and translation theory $[10,11,21,26,56]$ could therefore inform future investigations.

Author Contributions: Data collection, interviews, documentary analysis, writing-B.D. Conceptualisation, writing, editing-D.B.

Funding: This research received no external funding.

Acknowledgments: Burcin Demirbilek's PhD programme is supported by the Turkish Ministry of National Education.

Conflicts of Interest: The authors declare no conflicts of interest.

\section{Abbreviations}

$\begin{array}{ll}\text { WFD } & \text { Water Framework Directive } \\ \text { EU } & \text { European Union } \\ \text { IWRM } & \text { Integrated water resources management } \\ \text { RBAPs } & \text { River Basin Action Plans } \\ \text { RBMPs } & \text { River Basin Management Plans } \\ \text { WL } & \text { (Draft) Water Law }\end{array}$

\section{References}

1. Benson, D.; Gain, A.K.; Rouillard, J.J. Water governance in a comparative perspective: from IWRM to a 'nexus' approach? Wat. Altern. 2015, 8, 756-773.

2. Peters, B.G. Institutional Theory in Political Science: The New Institutionalism; Continuum: New York, NY, USA, 2012.

3. Börzel, T.A.; Risse, T. From Europeanisation to Diffusion: Introduction. West Eur. Pol. 2012, 35, 1-19. [CrossRef]

4. Bourblanc, M.; Crabbe, A.; Liefferink, D.; Wiering, M. The Marathon of the Hare and the Tortoise: Implementing the EU Water Framework Directive. J. Env. Plan. Man. 2013, 56, 1449-1467. [CrossRef]

5. Jager, N.W.; Challies, E.; Kochskämper, E.; Newig, J.; Benson, D.; Blackstock, K.; Collins, K.; Ernst, A.; Evers, M.; Feichtinger, J.; et al. Transforming European water governance? Participation and river basin management under the EU Water Framework Directive in 13 Member States. Water 2016, 8, 156. [CrossRef]

6. Boeuf, B.; Fritsch, O. Studying the implementation of the Water Framework Directive in Europe: A Meta-Analysis of 89 journal articles. Ecol. Soc. 2016, 21, 19.

7. Fritsch, O.; Adelle, C.; Benson, D. The EU Water Initiative at 15: origins, processes and assessment. Water Inter. 2017, 42, 425-442. [CrossRef]

8. Dolowitz, D.; Marsh, D. Learning from Abroad: The Role of Policy Transfer in Contemporary Policy-Making. Governance 2000, 13, 5-24. [CrossRef]

9. Demirbilek, B.; Benson, D. Legal Europeanisation in Three Dimensions: Water Legislation in Turkey. J. Water Law 2018, 25, 294-307.

10. Dolowitz, D.; Marsh, D. Who Learns What from Whom: a Review of the Policy Transfer Literature. Pol. Studies 1996, XLIV, 343-357. [CrossRef]

11. Benson, D.; Jordan, A. What have we learned from policy transfer research? Dolowitz and Marsh revisited. Pol. Studies Rev. 2011, 9, 366-378. [CrossRef]

12. Radaelli, C.M. Policy Transfer in the European Union; Institutional Isomorphism as a Source of Legitimacy. Governance 2000, 13, 25-43. [CrossRef]

13. Bulmer, S.; Padgett, S. Policy Transfer in the European Union: An Institutionalist Perspective. Brit. J. Pol. Sci. 2005, 35, 103-126. [CrossRef]

14. Bulmer, S.; Dolowitz, D.; Humphreys, P.; Padgett, S. Policy transfer in European Union governance; Routledge: Abingdon, UK, 2007. 
15. Lavenex, S. EU enlargement and the challenge of policy transfer: The case of refugee policy. J. Ethn. Migra. Stud. 2002, 28, 701-721. [CrossRef]

16. Onursal-Beşgül, O. Policy Transfer and Discursive DeEuropeanisation: Higher Education from Bologna to Turkey. Sou. Eur. Soc. Pol. 2016, 21, 91-103. [CrossRef]

17. Benson, D.; Jordan, A.; Huitema, D. Involving the public in catchment management: an analysis of the scope for learning lessons from abroad. Env. Pol. Gov. 2012, 22, 42-54. [CrossRef]

18. Sumer, V. Towards the New Water Framework Directive Notes on Water Draft Law; The Program of Water Research of ORSAM (Center for Middle Eastern Strategic Studies): Ankara, Turkey, 2012. Available online: https: / / www.academia.edu/2105912/Yeni_\%C3\%87er\%C3\%A7eve_Su_Kanununa_Do\%C4\%9Fru_ Su_Kanunu_Tasla\%C4\%9F\%C4\%B1_\%C3\%9Czerine_Notlar (accessed on 10 December 2018).

19. Sumer, V. Water and Politics in Turkey: Structural Change and EU Accession; I.B.Tauris: London, UK, 2016.

20. Yildiz, D.; Ozbay, O. Su ve Toprak; Dunya Yayincilik: Istanbul, Turkey, 2009.

21. Rose, R. What is lesson-drawing? J. Pub. Pol. 1991, 11, 3-30. [CrossRef]

22. Rose, R. Learning from Comparative Public Policy: A Practical Guide; Routledge: Abingdon, UK, 2005.

23. Jordan, A.; Liefferink, D. Environmental Policy in Europe: The Europeanization of National Environmental Policy; Routledge: Abingdon, UK, 2004.

24. European Union. Regulations, Directives and Other Acts; EU: Brussels, Belgium, 2018.

25. Prince, R. Policy transfer as policy assemblage: making policy for the creative industries in New Zealand. Env. Plan. A 2010, 42, 169-186. [CrossRef]

26. Stone, D. Transfer and translation of policy. Pol. Studies 2012, 33, 483-499. [CrossRef]

27. Pow, C.P. License to travel: Policy assemblage and the 'Singapore model'. City 2014, 18, 287-306. [CrossRef]

28. McCann, E.; Ward, K. A multi-disciplinary approach to policy transfer research: Geographies, assemblages, mobilities and mutations. Pol. Studies 2013, 34, 2-18. [CrossRef]

29. Benson, D.; Jordan, A. Policy transfer: Still evolving, not yet through? Pol. Studies Rev. 2012, 10, $333-338$. [CrossRef]

30. Hill, M. The Public Policy Process, 6th ed.; Routledge: Abingdon, UK, 2013.

31. Official Journal of the European Communities. Directive 2000/60/EC of the European Parliament and of the Council of 23 October 2000 establishing a framework for Community action in the field of water policy; Official Journal of the European Communities: Luxembourg, 2000.

32. International Commission for the Protection of the Danube River (ICPDR). River Basin District Management Plan-Update 2015; ICPDR Secretariat: Vienna, Austria, 2015.

33. European Commission. Report from the Commission to the European Parliament and the Council on the implementation of the Water Framework Directive (2000/60/EC): River Basin management Plans. Member State: Cyprus; European Commission: Brussels, Belgium, 2012.

34. Thelen, K. How Institutions Evolve: the Political Economy of Skills in Germany, Britain, the United States and Japan; Cambridge University Press: Cambridge, UK, 2004.

35. Tsur, Y. 'Pricing Irrigation Water in Turkey'. In Pricing Irrigation Water: Principles and Cases from Developing Countries; Tsur, Y., Roe, T., Doukkali, R., Dinar, A., Eds.; Resources for the Future/Taylor \& Francis: Washington, DC, USA, 2004.

36. Percin, S. General Outline of US, EU and Turkish Water Law; Ministry of Forestry and Water Affairs, General Directorate for Water Management: Ankara, Turkey, 2014.

37. Oktem, O. Water Politics and Political Culture: Turkey's Compatibility with the European Union; Springer International Publishing: Berlin, Germany, 2016.

38. Kibaroglu, A. 'Turkey's Water Policy Framework. In Turkey's Water Policy: National Frameworks and International Cooperation; Kramer, A., Scheumann, W., Eds.; Springer: Berlin, Germany, 2011.

39. Kibaroglu, A.; Sümer, V.; Scheumann, W. Fundamental Shifts in Turkey's Water Policy. Méditerranée 2012, 119, 26-34. [CrossRef]

40. Moroglu, M.; Yazgan, M. Implementation of EU Water Framework Directive in Turkey. Desalination 2008, 226, 271-278. [CrossRef]

41. Ministry of Agriculture and Forestry. Draft Water Law; Ministry of Agriculture and Forestry: Ankara, Turkey, 2012.

42. Ministry of EU. Chapter 27-Environment; Ministry of EU: Ankara, Turkey, 2017. 
43. Kibaroglu, A.; Sumer, V. Turkey's Draft Water Law and Water Framework Directive Implementation: An Analysis. Available online: https:/ / www.academia.edu/12931024/Turkeys_Draft_Water_Law_and_Water_ Framework_Directive_Implementation_An_Analysis (accessed on 4 November 2018).

44. Sabatier, P.A.; Focht, W.; Lubell, M.; Trachtenburg, Z.; Vedlitz, A.; Matlock, M. (Eds.) Swimming Upstream: Collaborative Approaches to Watershed Management; MIT Press: Cambridge, MA, USA, 2005.

45. Karaaslan, Y. Su Kanunu Tasarisi Taslagi; Directorate General of Water Management: Ankara, Turkey, 2014.

46. Ribamap. OUTPUT 18-Proposal for Futures Steps in Water Management. Report from the Technical Assistance for the Conversion of River Basin Action Plans into River Basin Management Plans; Ministry of Forestry and Water Affairs: Ankara, Turkey, 2017.

47. Ribamap. Draft version of the Konya Closed Basin Management Plan; Ministry of Forestry and Water Affairs: Ankara, Turkey, 2017.

48. Ribamap. Draft version of the Büyük Menderes River Basin Management Plan; Ministry of Forestry and Water Affairs: Ankara, Turkey, 2017.

49. DSI (General Directorate of State Hydraulic Works). Turkey Water Report; DSI: Ankara, Turkey, 2009.

50. Kankal, M.; Uzlu, E. The Status of Transboundary Rivers in Turkey. Water Res. 2014, 41, 649-665. [CrossRef]

51. Karpuzcu, M.; Gurol, M.D.; Bayar, S. Transboundary Waters and Turkey; Gebze Institute of Technology: Kocaeli, Turkey, 2009.

52. Kibaroglu, A. State-of-the-art review of transboundary water governance in the Euphrates-Tigris river basin. Int. J. Water Res. Dev. 2017, 35, 4-29. [CrossRef]

53. Aytüre, S. Su Kanununun AB Su Cerceve Direktifi Kapsaminda Degerlendirilmesi. Türk Bilimsel Derlemeler Dergisi 2016, 9, 65-71.

54. Liefferink, D.; Wiering, M.; Uitenboogaart, Y. The EU Water Framework Directive: A multi-dimensional analysis of implementation and domestic impact. Land Use Pol. 2011, 28, 712-722. [CrossRef]

55. Raadgever, G.T.; Dieperink, C.; Driessen, P.P.J.; Smit, A.A.H.; van Rijswick, H.F.M.W. Uncertainty management strategies: Lessons from the regional implementation of the Water Framework Directive in the Netherlands. Env. Sci. Pol. 2011, 14, 64-75. [CrossRef]

56. Mukhtarov, F. Rethinking the travel of ideas: policy translation in the water sector. Pol. Politics 2014, 42, 71-88. [CrossRef]

57. Pierson, P. Politics in Time: History, Institutions and Social Analysis; Princeton University Press: Princeton, NJ, USA, 2004.

58. EurEau. Position Paper "Cost Recovery and Water Pricing"; EurEau: Brussels, Belgium, 2016.

59. Moss, B. The Water Framework Directive: Total environment or political compromise? Sci. Tot. Environ. 2008, 400, 32-41. [CrossRef]

60. Zikos, D.; Thiel, A. Action Research's Potential to Foster Institutional Change for Urban Water Management. Water 2013, 5, 356-378. [CrossRef]

61. Zikos, D.; Roggero, M. The Patronage of Thirst: Exploring Institutional Fit on a Divided Cyprus. Ecol. Soc. 2013, 18, 25. [CrossRef]

62. Moss, T. Spatial Fit, from Panacea to Practice: Implementing the EU Water Framework Directive. Ecol Soc. 2012, 17, 2. [CrossRef]

63. Börzel, T.A.; Soyaltin, D. Europeanization in Turkey: Stretching a Concept to Its Limits? (KFG Working Paper Series, 36); Freie Universität Berlin, FB Politik- und Sozialwissenschaften, Otto-Suhr-Institut für Politikwissenschaft Kolleg-Forschergruppe “The Transformative Power of Europe”: Berlin, Germany, 2012.

64. Saatçioğlu, B. De-Europeanisation in Turkey: The Case of the Rule of Law. Sou. Eur. Soc. Pol. 2016, 21, 133-146. [CrossRef]

65. Yilmaz, G. From Europeanization to De-Europeanization: The Europeanization Process of Turkey in 1999-2014. J. Cont. Eur. Stud. 2016, 24, 86-100. [CrossRef]

66. Howlett, M.; Mukherjee, I.; Woo, J.J. From tools to toolkits in policy design studies: The new design orientation towards policy formulation research. Pol. Politics 2015, 43, 291-311.

(C) 2019 by the authors. Licensee MDPI, Basel, Switzerland. This article is an open access article distributed under the terms and conditions of the Creative Commons Attribution (CC BY) license (http:/ / creativecommons.org/licenses/by/4.0/). 